ENTREPRENEURSHIP AND SUSTAINABILITY ISSUES

ISSN 2345-0282 (online) http://jssidoi.org/jesi/ 2019 Volume 7 Number 1 (September)

http://doi.org/10.9770/jesi.2019.7.1(38)

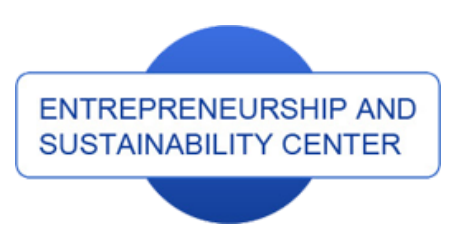

Publisher

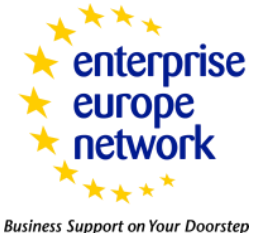

CASPA

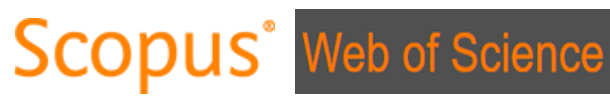

http://jssidoi.org/esc/home

1) Clarivate

Analytics

\title{
STUDY OF SECTOR-SPECIFIC INNOVATION EFFORTS: THE CASE FROM RUSSIAN ECONOMY*
}

\author{
Veronika Yu. Chernova ${ }^{1}$, Vasily S. Starostin ${ }^{2}$, Ekaterina A. Degtereva ${ }^{3}$, Inna V. Andronova ${ }^{4}$ \\ 1,2 State University of Management \\ 99, Ryazanskiy prospect st., Moscow, 109542, Russian Federation \\ ${ }^{1,3,4}$ Peoples' Friendship University of Russia \\ 6, Miklukho-Maklaya Str., Moscow, 117198, Russian Federation \\ E-mails: ${ }^{1}$ veronica.urievna@mail.ru; ${ }^{2}$ vs_starostin@guu.ru; ${ }^{3}$ degseb@mail.ru; ${ }^{4}$ Alv1207@mail.ru
}

Received 15 March 2019; accepted 5 Augusst 2019; published 30 September 2019

\begin{abstract}
Accelerated introduction of digital technology has recently become one of the key areas in development of Russian economy. The paper presents the approach to innovation intensity assessment by sector and economic activity. The method makes it possible to identify the growth intensity for an output of innovative products. This serves as an indicator of introduction of new technologies and a transition to a more high-tech conversion. The narration assumes that innovations in various sectors are unstable and uneven. There is an observation that there was the highest efficiency increase over the period under review in production and distribution of electrical power, gas, and water, and in other low-tech sectors (primarily, food production). There is a highly intensive character of innovations observed in high-tech and medium-tech sectors. There is another observation that the reasons for the unstable and multidirectional dynamics are as follows: high dependence of efficiency and intensity of innovations on external economic shocks, significant impact made by measures of state support on intensity of innovations, concentration of innovating at large-scale Russian and transnational companies. The results obtained led to the conclusion on a need in more stimuli for national demand from the part of Russian businesses for innovations, including digital technology.
\end{abstract}

Keywords: innovation, industrial economy, investments, competitiveness, levels of technological conversion, structural transformation of economy.

Reference to this paper should be made as follows: Chernova, V.Y.; Starostin, V.S.; Degtereva, E.A.; Andronova, I.V. 2019. Study of sector-specific innovation efforts: the case from Russian economy, Entrepreneurship and Sustainability Issues 7(1): 540-552. http://doi.org/10.9770/jesi.2019.7.1(38)

JEL Classifications: O14, O30

\footnotetext{
*This article was prepared with the financial support of the Russian Foundation for Basic Research (RFBR), the project "Enhancing Military-Economic Cooperation in the Space of the Collective Security Treaty Organization and the Eurasian Economic Union in the Context of the Sanctions Policy of Developed Countries and the Development of Import Substitution in the Russian Federation," No. 8-010-01132.
} 


\section{ENTREPRENEURSHIP AND SUSTAINABILITY ISSUES}

ISSN 2345-0282 (online) http://jssidoi.org/jesi/

2019 Volume 7 Number 1 (September)

http://doi.org/10.9770/jesi.2019.7.1(38)

\section{Introduction}

The development of digital economy in the past few years has become a priority development area. The next transformation wave in the society as its cause has the implementation of the so-called end-to-end digital technologies of the last generation (Vlasov et al., 2018). It is possible to describe artificial intelligence, the Internet of things, robotics, wireless solutions and other technology with such scale and impact potential that, according to some estimates, they might contribute to a growth of $40 \%$ (WEF, 2018). Labour productivity and their effective application will determinate global competitiveness of companies and countries.

Despite the fact that the scheduled vector of development in Russian economy and set tasks of a transition to the newest technology of digital economy deserve an unconditional support, digitalization experience in foreign countries shows that accelerated introduction of digital technology is successful despite encounters some issues (Abdrakhmanov et al., 2019). It is usually and only possible to implement the set tasks if a number of fundamental conditions has been met. (A) There are established development strategies in place that assume a fundamental change in ways of organization and operations through intensive introduction of digital technology. (B) In a country, there is a sector of the process-related supply in place able at least to transfer and adjust overseas digital solutions. (C) There is a growing demand for digital technology from production sectors of economy.

In this vein, an analysis of preparedness of Russian economy for digitalization and building of a comprehensive industrial digital environment has become currently central. Therefore, a purpose of this paper is an estimate of intensity that innovations have in various sectors of Russian economy against relevant indicators.

\section{Review of literature}

Innovating as a priority for development of Russian economy has become relatively recently a central issue. Management of innovations requires knowledge of their regularities, challenges, and specifics by sector. Official statistics for Russia contains an extremely limited number of indicators that describe innovating. Many researchers pay attention to limited data on the technological development in a number of sectors (Spitsin, 2010; Barinova et al., 2018, etc.). Methodology-related challenges obstruct a comparative sector-specific analysis due to a lack of a shared approach to measurements of innovation intensity (Starodubova \& Misbakhova, 2016; Lavrovsky, 2018; Motova, 2016).

The academic mainstream has consolidated the idea that digital innovations are the most important lever to address current economic challenges. Researchers are exploring digital economy from various perspectives. They consider digital transformation phenomenon in terms of principles, infrastructure support, institutional foundations, etc. (Istomina, 2018). They generally accept that digital technological changes are a main trigger for the today's economic growth that contributes to higher labour productivity. Experts generally agree that it is digital technologies that will determinate a shape of future economy (Blinkin, et al., 2019).

An economic effect of digitalization in industry is diverse and spreads over technical processes, production arrangements, applications of tools of labour. Applications of digital technologies in a number of sectors might contribute to a higher number of enterprises owing to a less number of entry barriers to new markets. Such a trend is clear from dynamics of a number of companies in technologically challenging sectors of economy (for details, see Kuzmin, 2018; Kuzmin \& Guseva, 2016). At the same time, there might be also a risk of market monopolization and appearance of new barriers to the development of small and medium-sized businesses (Brynjolfsson et al., 2008; Litau, 2018a; Litau, 2018b; Tvaronavičienė, 2018). Barinova et al. (2018) provided a detailed analysis of significant characteristics of the development of technologically challenging sectors of Russian economy, as well as limitations for their development. Goraeva and Shamina (2014) developed the 


\section{ENTREPRENEURSHIP AND SUSTAINABILITY ISSUES}

ISSN 2345-0282 (online) http://jssidoi.org/jesi/

2019 Volume 7 Number 1 (September)

http://doi.org/10.9770/jesi.2019.7.1(38)

methodology to measure the development of high-tech economic activities based on the application of the sector wide approach.

Lavrovsky (2018) proposed the approach that enables measuring and evaluating of innovation intensity based on an assessment of investment efforts and indicators of labour performance dynamics caused by them. Motova (2016) proposes to evaluate innovations with the cluster approach by a given set of indicators. They include the growth in a number of enterprises showing innovative activity, higher number of their employees, higher costs for $\mathrm{R} \& \mathrm{D}$ in the field of innovations, higher costs and a larger share of costs for design, higher costs and a larger share of costs for investments in machinery and equipment in a structure of costs for technological innovations, higher output of innovative products, higher ratio between the output of innovative products and costs for technological innovations. Cluster distribution of explored objects following the method by Motova is achieved from a deviation of an average value of an indicator in the cluster from an average value across the entire set of objects. That makes it possible to identify leaders.

Starodubova and Misbakhova (2016) propose to do a quantitative measurement of innovations by economic activities using four indicators. They include growth rates of an output of shipped goods, proportion of innovative products against all the shipped goods, proportion of innovation organizations in a total number of organizations; growth rates of costs for technological innovation. At the same time, in accordance with the approach proposed by authors, the innovative activity gets higher as far as: (a) growth rates of the volume of the shipped innovative goods and growth rates of costs for technological innovations approach 150\%; (b) share of innovative products of all the shipped goods approaches $40 \%$; and (c) share of organizations that innovate approaches $35 \%$ in a total number of organizations.

The reviewed methods for an estimate of the innovation potential in economy have significantly contributed to a study of innovations at a meso-level. However, so far, the issue of evaluation with regard to intensity and efficiency of innovations in certain sectors has been not explored enough. Support to priority areas of economic development requires an accessible and simple tool to select and justify promising innovations, carry out monitoring of innovations in certain sectors.

\section{Materials and Methods}

The research was based on official data as provided by the research information base of the Federal State Statistics Service of Russia (Rosstat). Evaluation of innovations of enterprises was based on proposed indicators.

To separate types of economic activity within the manufacturing industry by their technological development, we follow the approach by Rosstat (Rosstat Order of January 14, 2014 No. 21) applied until 2018. Currently, there is a new approach (Rosstat Order of December 15, 2017 No. 832) in use, developed by grouping of high-tech and medium-tech levels by Eurostat in NACE Rev.2 (Eurostat), taking into account OECD recommendations (Galindo-Rueda and Verger, 2016) and specifics of national economy.

In compliance with all of the above mentioned approaches, there are 4 groups of industries: high-tech (ratio between costs for R\&D and added value cost is at least 8\%), medium-tech of the high level (ratio between costs for $\mathrm{R} \& \mathrm{D}$ and added value cost is $2.5 \%-8 \%$ ), medium-tech of the low level (ratio between costs for R\&D and added value cost is $1.0 \%-2.5 \%$ ) and low-tech industries (ratio between costs for R\&D and value added cost is $0 \%$ $1 \%)$.

In Russian practice, a key criterion for grouping of industries by signs of technological development and classification as a high-tech sector of economy is intensity of research in it, due to limited data on other possible indicators of technological development. 
The intensive development in an industry depends on a growth of return on a use of available resources and investments, while the extensive development in the industry is dependent on an increase in costs and volumes of raised resources (Dahdueva, 2011).

Innovation efficiency $\left(E_{I A}\right)$ one might find as a ratio between a result from innovations $\left(Q_{I A}\right)$, determined by volume of shipped innovative products and costs for technological innovations $\left(C_{I A}\right)$ :

$$
E_{I A}=\frac{Q_{I A}}{C_{I A}}
$$

An increment rate of indicators of innovations' result is a velocity of ongoing changes:

$$
R_{Q_{I A}}=\frac{Q_{I A i}-Q_{I A(i-1)}}{Q_{I A(i-1)}},
$$

where $R_{Q_{I A}}$ is an increment rate for a result of innovations, $Q_{I A i}$ is a shipping volume of innovative products by branch, $i$ is a period of time (year).

$$
R_{C_{I A}}=\frac{C_{I A i}-C_{I A(i-1)}}{C_{I A(i-1)}}
$$

where $R_{C_{I A}}$ is an increment rate for costs for technological innovations, $C_{I A i}$ is costs for technological innovations.

$$
R_{E_{I A}}=\frac{E_{I A i}-E_{I A(i-1)}}{E_{I A(i-1)}},
$$

where $R_{E_{I A}}$ is an increment rate for innovation efficiency, $E_{I A i}$ is innovation efficiency.

The increment rate of efficiency might serve as a measure of innovation intensity. The higher the value of this indicator is, the more the higher output of innovative products exceeds the increase in costs and vice versa. If the indicator of the increment rate of innovation efficiency takes a negative value, this might mean extensification of the innovative product output.

Digital technologies are distinct by their ability to make labour productivity higher in a many-fold manner and, hence, the output, ceteris paribus. Thus, in the sectors of economy, in which digital technologies are being introduced and applied, we should observe higher efficiency of innovations.

Let us introduce the concept of an intensity indicator for innovations $\left(I_{I A}\right)$, considered as a ratio between the growth rate of innovation efficiency and growth rate of costs for technological innovations:

$$
I_{I A}=\frac{E_{I A_{i}}}{E_{I A_{i-1}}} / \frac{C_{I A_{i}}}{C_{I A_{i-1}}} .
$$

If the efficiency growth rate exceeds the costs' growth rate, one may conclude of the predominantly intensive growth in an output of innovative products, which is typical for the newest technologies, including digital ones. Otherwise, there is an extensive growth of innovative products, mainly due to increased costs with limited introduction of breakthrough solutions. 


\section{ENTREPRENEURSHIP AND SUSTAINABILITY ISSUES}

ISSN 2345-0282 (online) http://jssidoi.org/jesi/ 2019 Volume 7 Number 1 (September) http://doi.org/10.9770/jesi.2019.7.1(38)

\section{Results}

The assessment of intensity of innovations in industries and certain types of economic activity was done using indicators of a volume of shipped innovative products and costs for technological innovations (Tab. 1). Note that intensity of costs for R\&D in some sectors of Russian economy was significantly lower than the levels defined by OECD. In other words, even the most high-tech industries in Russia are less advanced than the same in the countries that apply the OECD approach. Moreover, in itself, the fact that a company has a particular type of activity does not say anything of its actual innovative activity. For instance, pharmaceutical companies in Russia often only pack products made by other countries instead of the development of new products or their production (Barinova, Zemtsov \& Lanshina, 2018).

Table 1. Results and costs of innovations in sectors and industries of Russian economy in 2012-2017

\begin{tabular}{|c|c|c|c|c|c|c|}
\hline Industries and economic activities & 2012 & 2013 & 2014 & 2015 & 2016 & 2017 \\
\hline \multicolumn{7}{|c|}{ Volume of shipped innovative products, works, and services, billion roubles } \\
\hline Mineral production & 522.89 & 523.21 & 648.53 & 368.40 & 419.98 & 489.45 \\
\hline Manufacturing industries, total, including & $1,973.54$ & $2,518.62$ & $2,362.39$ & $2,856.25$ & $3,196.99$ & $2,832.80$ \\
\hline $\begin{array}{l}\text { high-tech and medium-tech of the high } \\
\text { level }\end{array}$ & 992.66 & $1,164.91$ & $1,047.39$ & $1,096.49$ & $1,185.85$ & $1,341.03$ \\
\hline medium-tech of the low level & 292.93 & 344.90 & 408.36 & 464.42 & 415.98 & $1,112.64$ \\
\hline low-tech, including & 121.30 & 158.42 & 222.70 & 275.80 & 305.60 & 379.14 \\
\hline food production & 113.18 & 127.82 & 180.28 & 209.29 & 236.95 & 316.66 \\
\hline $\begin{array}{l}\text { Production and distribution of electric } \\
\text { power, gas, and water }\end{array}$ & 13.18 & 30.70 & 26.49 & 33.60 & 106.72 & 80.80 \\
\hline Research and development & 283.96 & 344.65 & 464.19 & 482.30 & 517.93 & 605.65 \\
\hline Agriculture & & & & & 22.22 & 28.45 \\
\hline \multicolumn{7}{|l|}{ Costs for tech innovations, RUB bln } \\
\hline Mineral production & 87.78 & 94.53 & 123.90 & 125.58 & 136.70 & 184.81 \\
\hline Manufacturing industries, total, including & 430.46 & 580.12 & 565.58 & 563.49 & 574.15 & 610.22 \\
\hline $\begin{array}{l}\text { high-tech and medium-tech of the high } \\
\text { level }\end{array}$ & 155.08 & 226.83 & 214.15 & 242.91 & 279.05 & 224.12 \\
\hline medium-tech of the low level & 211.21 & 271.06 & 276.83 & 226.51 & 188.85 & 307.74 \\
\hline low-tech, including & 31.71 & 43.84 & 35.57 & 27.56 & 40.64 & 78.36 \\
\hline production of foods & 16.91 & 29.97 & 25.86 & 20.14 & 26.08 & 50.71 \\
\hline $\begin{array}{l}\text { Production and distribution of electric } \\
\text { power, gas, and water }\end{array}$ & 65.43 & 72.14 & 73.29 & 46.69 & 66.66 & 53.02 \\
\hline Research and development & 226.78 & 289.46 & 387.83 & 383.50 & 416.73 & 468.87 \\
\hline Agriculture & - & - & - & - & 14.83 & 15.81 \\
\hline
\end{tabular}

Source: computed by the author from Rosstat (2019)

As calculations have shown, efficiency of innovations in various sectors of economy is extremely unstable and uneven (Fig. 1). In 2012-2015, lower efficiency of innovations in mineral production was followed by a slow growth in 2016, but as early as in 2017, dynamics of efficiency showed a downward trend again. There is also a similar change in trends from downward to upward and again to downward that we observe in the manufacturing industry. However, in high-tech and medium-tech industries of high level, the downward trend was longer (until 2016). 


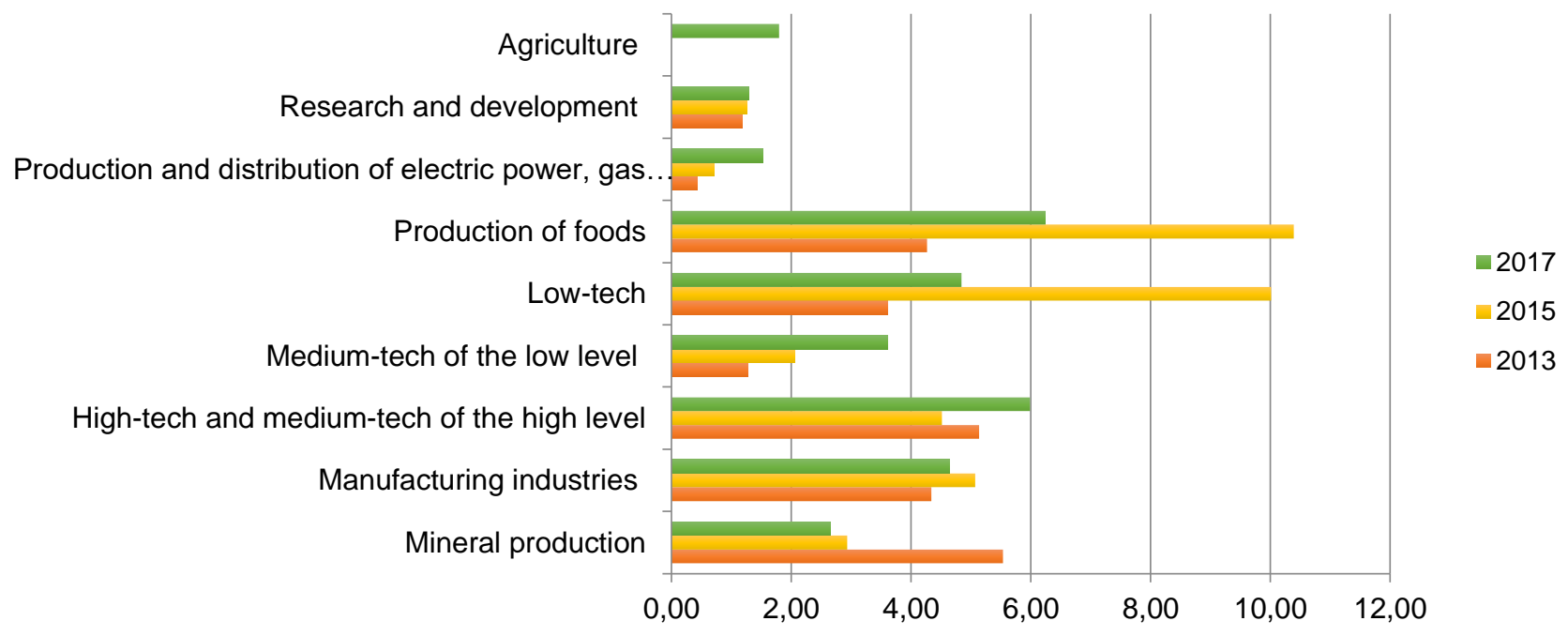

Fig. 1. Industry efficiency dynamics

Source: computed by the author from Rosstat (2019)

The increased efficiency of innovations in high-tech industries was driven by government support measures, including those aimed at promotion of the external demand for products of these industries (Government of the Russian Federation). Thus, in Russia, there is the program of subsidies for interest rates on loans that Vnesheconombank and Roseximbank provide to foreign customers purchasing Russian high-tech products. The Ministry of Economic Development provides non-financial support to exports of high-tech products in Russia via overseas trade missions of Russia. Such support includes informational, consulting, and organizational assistance. Besides, Russian producers might benefit from subsidies for registration of intellectual property in overseas markets and receive an indemnity for a part of the costs for product certification to enter the global market.

In 2015 , the growth of innovations in the food industry was driven by the import substitution policy and the embargo on import of a range of food products introduced in 2014. The food industry in Russia is in a period of its active development. Over the recent 4 years, it has been a driver in the industrial production. Upon introduction of the food embargo in 2014, Russia restructured its imports and started the active development of its agriculture. In agriculture, over 6 years of the program, the output has increased by more than 50\%. The largest TNCs (PepsiCo, Danone, Coca-Cola Hellenic Bottling, Mars, and Mondelez International), included in TOP-10 largest food producers and investors (localization of their production facilities and modernization of existing facilities) have had a significant impact on the growth of innovations in the industry (Kheyfets \& Chernova, 2018).

There is a steady increase in efficiency of innovations without a sharp change in directions of dynamics observed in the research and development sector, and there is the same situation in agriculture. There was the highest rate of changes in efficiency in the period under study observed in production and distribution of electric power, gas, and water (Fig. 2), low-tech industries owing to food production, in medium-tech and high-tech industries. 


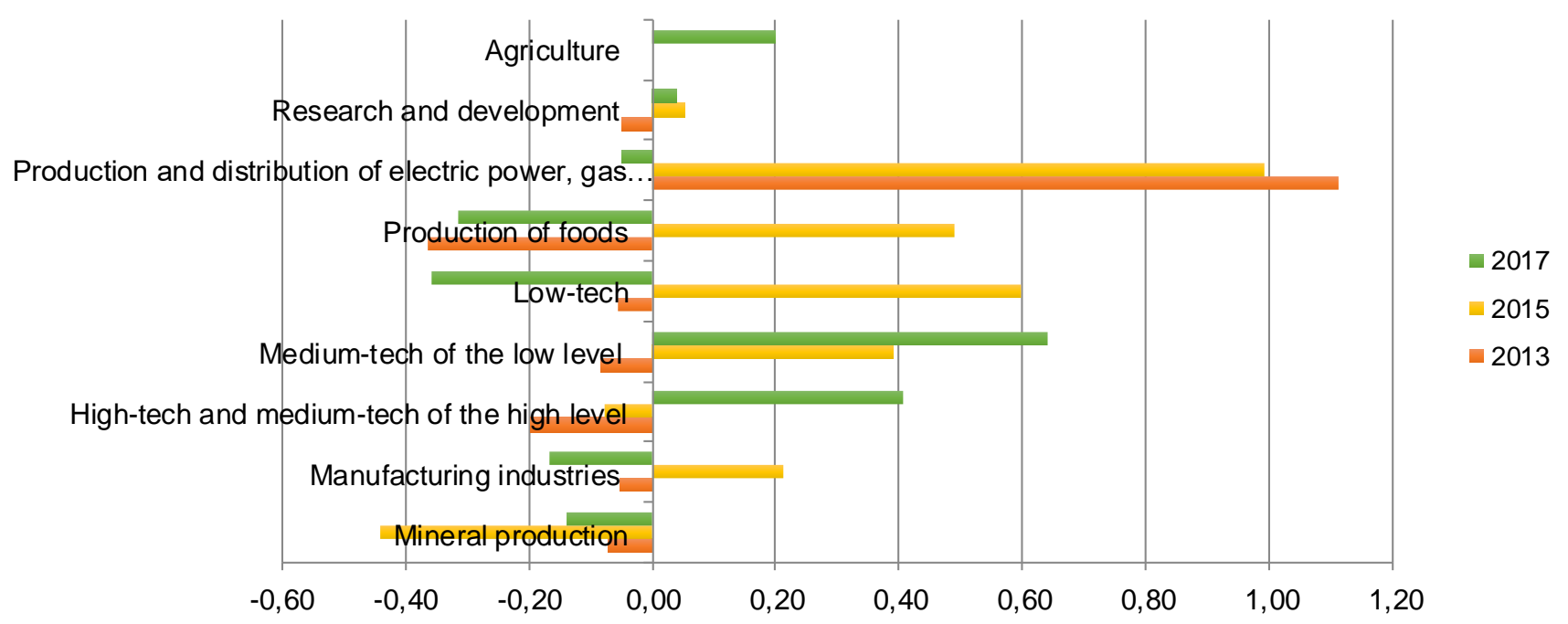

Fig. 2. Increment rate of innovations efficiency

Source: computed by the author from Rosstat (2019)

Dynamics of changes in efficiency of innovations in the sector of production and distribution of electric power, gas, and water is dependent on innovations at separate largest energy-generating enterprises in Russia. In general, a share of R\&D costs at Russian energy-generating companies is insignificant. Thus, Rosseti annually spends about RUB1.0 billion for an entire R\&D program, RusHydro - RUB0.4 billion, Inter RAO - RUB0.2 billion, and Gazprom Energoholding - RUB0.35 billion (Innovations in power sector: from formal R\&D to future technology, 2019). R\&D costs at the vertically integrated nuclear energy company (4.5\% of revenue) (Rosatom), unlike other Russian energy-generating companies, are in absolute terms comparable to leaders in foreign energy-generating sector. French EDF spends $0.9 \%$ of its revenue for research, Spanish Iberdrola - 0.8\%, Swedish Vattenfall - 0.5\%, and Canadian HydroQuebec - $0.9 \%$.

In many sectors of Russian economy, development and production of innovative products have become only possible because of high-tech imported components used in their structure. Complicated geopolitics and relations between Russia and Western countries have seriously hampered both production of innovative high-tech products, and their sales in export markets, even in terms of the import substitution policy. Moreover, the development of import-substituting facilities requires significant long-term investments. Russia has not only faced such weaknesses of innovation-driven manufacturing facilities in the power sector, but also in a number of other industries (Klochkov, 2017). 


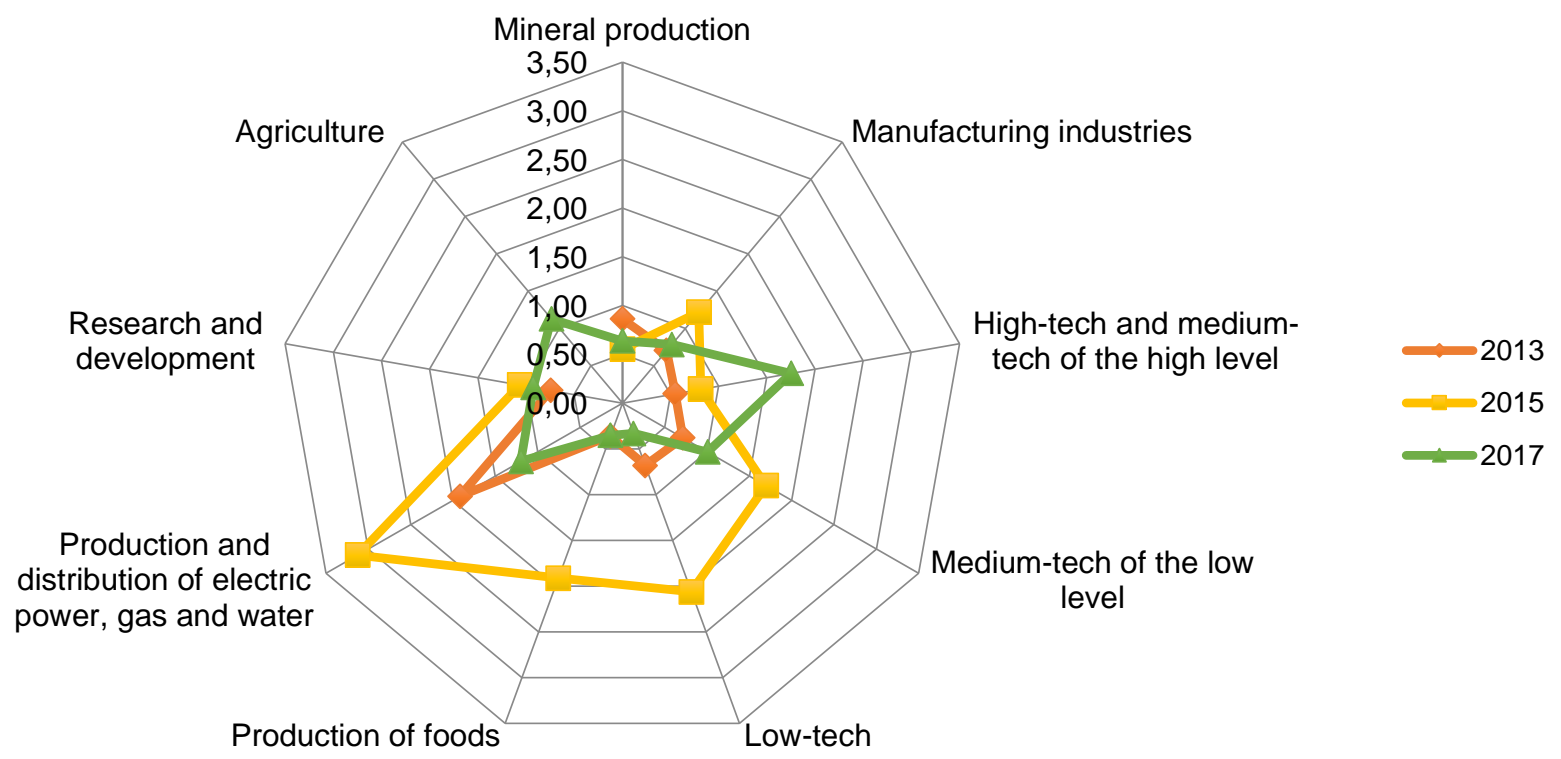

Fig. 3. Innovation intensity indicator

Source: computed by the author from Rosstat (2019)

The intensity of innovations, increased in 2017, in high and medium-tech industries of the medium-tech level (Fig. 3), is associated with an increased output of innovative products in the military-industrial complex (Barinova, Zemtsov and Lanshina, 2018). An indirect proof of this statement might be absolute leadership in proceeds from exported technologies in one of the high-tech industries, production of aircrafts, including spacecrafts (SRI HSE Institute of Statistics and Economy of Knowledge, 2016). In 2015, enterprises of this industry earned $\$ 60,137$ million from exported technology, while their share of exported products was about 30\%, while Russia mainly met its needs in civilian aircrafts and helicopters from imported goods (Bogachev, 2017).

\section{Discussion}

The completed research has confirmed conclusions by other researchers of unstable efficiency of innovations in Russian economy. Thus, Starodubova and Misbakhova (2016) show that in the petrochemical industry, in 20122014, a nature of innovations turned from optimal to unstable, whereas in the chemical industry and production of rubber and plastic products, innovations downgraded from unstable to the low level.

Motova (2016) comes to a similar conclusion based on data on innovations in industries of Russian economy and the cluster approach. The grouping attempt for main types of economic activities depending on intensity and efficiency of their innovations shows that it is impossible today to single out any cluster as a leader in innovations.

In Russian economy, a small number of innovatively active enterprises is typical (on the average for economy, it was $8.5 \%$ in 2017). It is several times smaller than in the developed countries (for example, in Germany, 50- 


\section{ENTREPRENEURSHIP AND SUSTAINABILITY ISSUES}

ISSN 2345-0282 (online) http://jssidoi.org/jesi/ 2019 Volume 7 Number 1 (September) http://doi.org/10.9770/jesi.2019.7.1(38)

$60 \%$ ), while a proportion of costs for technological innovations in the total volume of shipped products is at the level of leading countries (2.9\% in 2014; $2.4 \%$ in 2017; in Germany, 2.12\%; in Sweden, 2.98\%). This implies that innovatively active enterprises invest in new technologies at the level of world's leaders and that innovation processes are largely concentrated at large-scale companies in contrast to many developed countries, where small and medium-sized enterprises are a driving force of innovations (Bogachev, 2017).

Despite the fact that in Russia, ICT introduction has got a status of a key development direction, at the current stage of formation of digital economy, there are fundamentally new engineering, organizational and managerial challenges. One of the problems in introduction of digital innovations in the real sector of economy is that there are almost no proven methods for digital transformation of companies in realias of digital economy. This is because the digitalization process started only a short time ago.

Main obstacles to digital transformation, according to businesspersons (Zemtsov, 2019), as a number of factors that one might divide into three groups (Fig. 4).

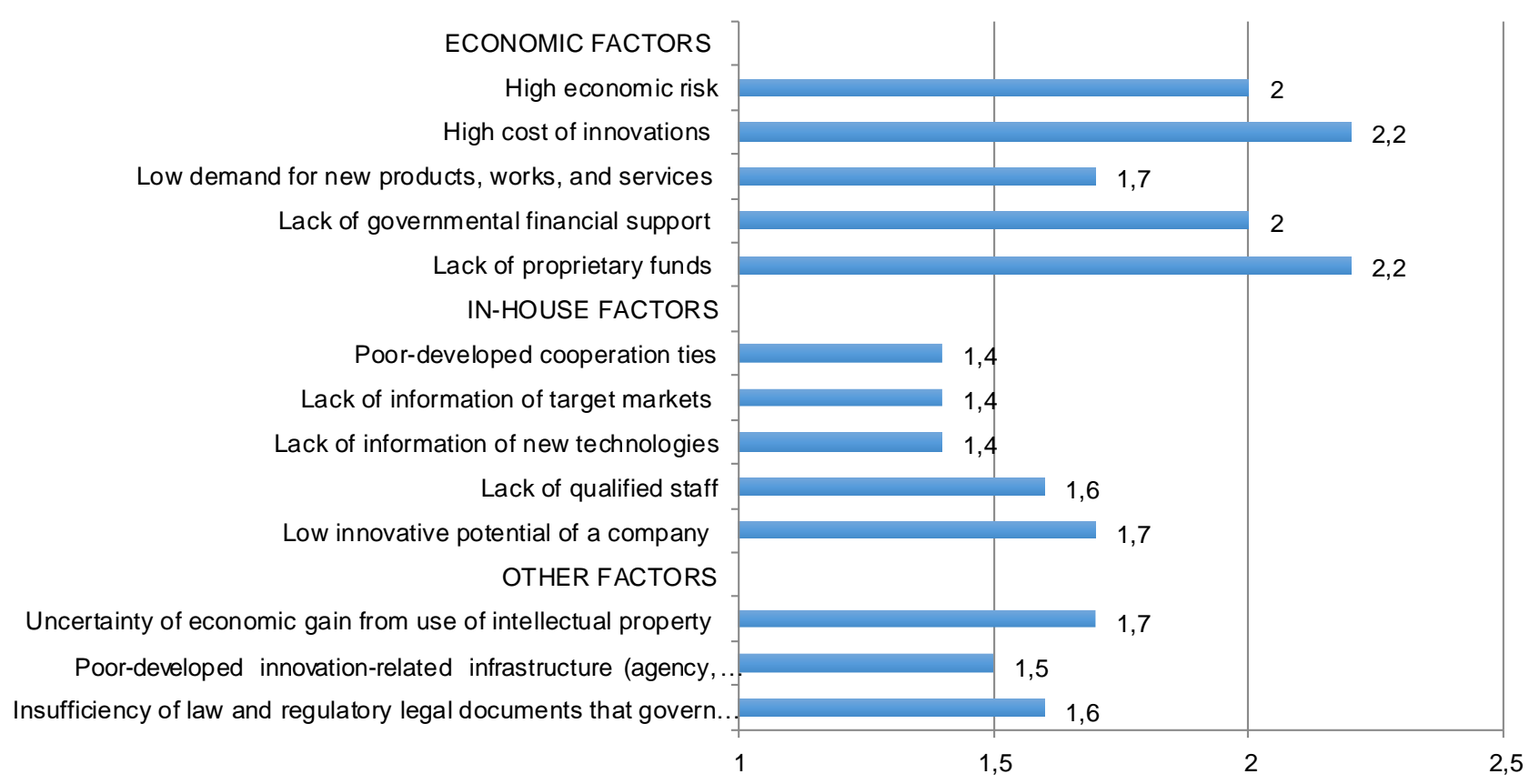

Fig. 4. Barriers to digital transformation of business

Source: compiled by the author from Zemtsov, 2019

Both national and international surveys of businesspersons show that prospects for an economic return on production digitalization are yet unclear. Introduction of such technologies is technically and organizationally challenging and capital-intensive, while a level of a possible additional income is poorly predictable (Plotnikov, 2018). The research of outcomes that introduced digital technologies had brought points out to unsuccessful implementation efforts. Sixteen percent respondents only say that at their companies, digital transformations have contributed to a long-term efficiency increase. Another 7 percent of respondents claim that they observed higher, but unsustainable efficiency. In conventional industries of economy, 7-11\% of companies were only able to achieve success in their digital transformations (McKinsey, 2018.). 


\section{ENTREPRENEURSHIP AND SUSTAINABILITY ISSUES}

ISSN 2345-0282 (online) http://jssidoi.org/jesi/ 2019 Volume 7 Number 1 (September) http://doi.org/10.9770/jesi.2019.7.1(38)

Despite serious penetration of digital technologies in media and retail sectors (NRU "HSE", 2019), their penetration depth is on average below 40\% (NRU "HSE", 2019a). The influence of digitalization on the revenue growth has also turned out to be questionable: the deeper penetration of digitalization into traditional industries makes constraints for the income and profit growth in lower-quartile companies and disproportionately influences performance indicators of upper-quartile companies (McKinsey, 2017).

The state support in individual industries is surely a significant factor of intensity in introduction of digital technologies. In 2017, compared to 2010, a share of funds from the federal budget in a structure of costs for technological innovations increased by $22.8 \%$ with a decline in foreign investment from $2.4 \%$ to $1 \%$ and a share of enterprises' proprietary funds by $17.3 \%$ (Statistics of Science and Education, 2018). There are significant differences between industries in a number of organizations benefitting from the government support. For instance, in the research and development sector, about $69 \%$ of organizations benefit from the government support. About 30\% - in the high-tech industry, about 12\% - in the manufacturing industry on average, and only $4 \%$ in low-tech industries (Zemtsov, 2019). Nevertheless, the food industry, in which only $1.7 \%$ of enterprises benefitted from the government support, shows high rates of innovations, while the research and development sector shows a stable but moderate increase in efficiency and intensity of innovations. Poor innovation activity in the manufacturing industry that produces a demand for innovations is a possible reason for this. Inefficiently spent financial resources is another reason.

\section{Conclusion}

One might apply the proposed approach to measurements of intensity of innovations for a comparative assessment of innovation processes in certain sectors of economy. It makes it possible to measure whether the growth is intense as applied to an output of innovative products. This serves as an indicator of introduction of new technologies and a transition to more high-tech conversion.

The completed study has showed that sectors of Russian economy typically show unsustainable dynamics of effort in the field of innovations. This is due to a number of factors, including the following: concentration of innovation efforts at large-scale Russian businesses and TNCs, high dependence between efficiency and intensity of innovations on external economic shocks (sanctions, embargo, intensified competition at overseas markets, etc.), significant impact on intensity of innovations from measures of government support, growth of innovation efforts in high-tech industries has been largely ensured by the military-industrial complex and promoted export of high-tech products with the insufficient national demand. An intensive nature of innovation efforts is clear in high-tech and medium-tech industries of the high-level, in production and distribution of electric power, gas and water, as well as agriculture.

\section{Acknowledgments}

This article was prepared with the financial support of the Russian Foundation for Basic Research (RFBR), the project "Enhancing Military-Economic Cooperation in the Space of the Collective Security Treaty Organization and the Eurasian Economic Union in the Context of the Sanctions Policy of Developed Countries and the Development of Import Substitution in the Russian Federation," No. 8-010-01132. 


\section{ENTREPRENEURSHIP AND SUSTAINABILITY ISSUES}

ISSN 2345-0282 (online) http://jssidoi.org/jesi/ 2019 Volume 7 Number 1 (September)

http://doi.org/10.9770/jesi.2019.7.1(38)

\section{References}

Abdrakhmanov, G.I. et al. (2019). What is Digital Economy? Trends, Competencies, Measurement: Report to XX Apr. International Scientific Conf. on Problems of Economic and Social Development (Moscow, April 9-12, 2019). Moscow: Publ. House of Higher School of Economics.

Barinova, V., Zemtsov, S. \& Lanshina, T. (2018). Development of High-Tech Sector in the Economy in Russia. Retrieved from https://ssrn.com/abstract=3123060 or https://doi.org/10.2139/ssrn.3123060

Blinkin, M.Ya., et al. (2019). Regulatory Development: New Challenges in Terms of Crucial Technological Changes: Report to XX Apr. International Scientific Conf. on Problems of Economic and Social Development (Moscow, April 9-12, 2019). Moscow: Publ. House of the Higher School of Economics.

Bogachev, Yu.S. (2017). Producible structure as a factor of Russian economy sustainable development. Strategicheskiy Menedzhment, 3, 21-29.

Bondarenko, V.M. (2018). Structural modernization in terms of digital economy formation. MIR (Modernizatsiya. Innovatsii. Razvitiye), 9(2) (34), 172-191. https://doi.org/10.18184/2079-4665.2018.9.2.172-191

Brynjolfsson, E., McAfee, A., Sorell, M. \& Zhu, F. (2008). Scale without mass: Business process replication and industry dynamics. Harvard Business School Technology \& Operations Mgt. Unit Research Paper No. 07-016. Retrieved from SSRN https://ssrn.com/abstract=980568 or https://doi.org/10.2139/ssrn.980568

Dahdueva, K.D. (2011). Problems and features of distinction between extensive and intensive development ways of an industrial enterprise. Transport Business of Russia, 3, 101-102.

European Conference on Innovation and Entrepreneurship, ECIE (pp. 394-401).

Eurostat. Statistics explained. Glossary: High-tech classification of manufacturing industries. Retrieved from https://ec.europa.eu/eurostat/statistics-explained/index.php/Glossary:High-tech_classification_of_manufacturing_industries

Galindo-Rueda, F. \& Verger, F. (2016), “OECD Taxonomy of Economic Activities Based on R\&D Intensity”, OECD Science, Technology and Industry Working Papers, 2016/04. Paris: OECD Publishing. https://dx.doi.org/10.1787/5jlv73sqqp8r-en

Goraeva, T.Yu. \& Shamina, L.K. (2014). Evaluation of development of high-tech types of economic activity. Scientific and Technical Statements of the St. Petersburg State Polytechnic University. Economics, 6(209), 113-123.

Government of the Russian Federation. Non-commodity Export Support. Retrieved from http://government.ru/rugovclassifier/599/main/

NRU “HSE”. (2019). Digital Activity of Retailers. Moscow: NRU “HSE”. Retrieved from https://issek.hse.ru/news/245193640.html

NRU “HSE”. (2019a). Digital Economy. A Brief Statistical Compilation. Moscow: NRU "HSE”.

Innovations in power sector: from formal R\&D to future technology. (2019.). Energetika i Promyshlennost' Rossii, 5(361). Retrieved from https://www.eprussia.ru/epr/361/1509722.htm

Istomina, Ye.A. (2018). Methodology assessment of trends in the digital economy of industry. CSU Bulletin, 12(422), 108-116. https://doi.org/10.14529/em180312

Kheyfets, B.A., Chernova, V.Yu. (2018). Adaptation of market strategies of TNCs in Russia in the context of import substitution policy. European Research Studies Journal, 21(3), 192-205.

Klochkov, V.V. (2017). Analysis of the impact of technological changes in energy sector on sustainability of Russian economy. National Interests: Priorities and Security, 13(4) (349), 684-698.

Kuzmin, E.A. (2018). Data on empirically estimated corporate survival rate in Russia. Data in Brief 16. https://doi.org/10.1016/j.dib.2017.12.011 


\section{ENTREPRENEURSHIP AND SUSTAINABILITY ISSUES}

ISSN 2345-0282 (online) http://jssidoi.org/jesi/ 2019 Volume 7 Number 1 (September) http://doi.org/10.9770/jesi.2019.7.1(38)

Kuzmin, E.A. \& Guseva, V.E. (2016). Survival rate and lifecycle in terms of uncertainty: Review of companies from Russia and Eastern Europe. Journal of Advanced Research in Law and Economics. https://doi.org/10.14505/jarle.v7.7(21).23

Lavrovsky, B.L. (2018). Assessment of innovation intensity: the case of USA. Ekonomika Regiona, 14(1), 281-291. https://doi.org/10.17059/2018-1-22

Litau, E. (2018a). Information flows management as a way to overcome "puberty challenges" of a small enterprise. In ACM International Conference Proceeding Series (pp. 34-38). https://doi.org/10.1145/3278252.3278259

Litau, E. (2018b). The information problem on the way to becoming a "Gazelle." In Proceedings of the European Conference on Innovation and Entrepreneurship, ECIE (Vol. 2018-September, pp. 394-401).

McKinsey. (2017). The Case for Digital Reinvention. Retrieved from https://www.mckinsey.com/business-functions/digital-mckinsey/ourinsights/the-case-for-digital-reinvention

McKinsey. (2018). Unlocking success in digital transformations. Retrieved from https://www.mckinsey.com/businessfunctions/organization/our-insights/unlocking-success-in-digital-transformations

Motova, M.A. (2016). Determination of Russian innovative activity tendencies. Statistics and Economics, 6, 58-63. https://doi.org/10.21686/2500-3925-2016-6-58-63

Plotnikov, V.A. (2018). Digitalization of production: the theoretical essence and development prospects in the Russian economy. Izvestiya Sankt-Peterburgskogo Gosudarstvennogo Ekonomicheskogo Universiteta, 4(112), 16-24.

Romanova, O.A., Korovin, G.B. \& Kuzmin, E.A. (2017). Analysis of the development prospects for the high-tech sector of the economy in the context of new industrialization. Espacios, 38(59), 25.

Rosatom. Science and Innovations. Innovative Activity. Retrieved fromhttps://niirosatom.ru/o-kompanii/innovatsionnaya-deyatelnost/

Rosstat Order of January 14, 2014 No. 21 "On Approval of Methodology to Estimate Indicators "Share of High-tech and Knowledgeintensive Sectors in GDP" and "Share of High-tech and Knowledge-intensive Sectors in GRP." Retrieved from https://www.glavbukh.ru/npd/edoc/99 499076991

Rosstat Order of December 15, 2017 No. 832 (as amended on January 17, 2019) "On Approval of Methodology to Estimate Indicators "Share of High-tech and Knowledge-intensive Products in Gross Domestic Product" and "Share of high-tech and Knowledge-intensive Products in Gross Regional Product of a Subject of the Russian Federation." Retrieved from http://rulaws.ru/acts/Prikaz-Rosstata-ot$\underline{15.12 .2017-\mathrm{N}-832 /}$

Rosstat. (2019). Official Statistics. Science, Innovation and Information Society. Science and Innovations. Retrieved from http://www.gks.ru/wps/wcm/connect/rosstat_main/rosstat/ru/statistics/science_and_innovations/science/\#

Spitsin, V.V. (2010). Comparative analysis of innovation activity rates of Russia and foreign countries. Tomsk State University Journal, $331,153-158$.

SRI HSE Institute of Statistics and Economy of Knowledge. (2016). Foreign Trade of Russian Technology by Economic Activity. Retrieved from https://issek.hse.ru/data/2016/08/11/1118252870/NTI_N_11_10082016.pdf

Starodubova, A.A. \& Misbakhova, Ch.A. (2016). Evaluation of innovation activity of certain types of economic activity. Economic Analysis: Theory and Practice, 7(454), 175-184.

Statistics of Science and Education. (2018) Issue 4. Innovative Activity in the Russian Federation. Info-stat. Mat. Moscow: FSBSI SRI FRCEC.

Tvaronavičienè, M. (2018). Towards internationally tuned approach towards critical infrastructure protection, Journal of Security and Sustainability Issues, 8(2), 143-150. https://doi.org/10.9770/jssi.2018.8.2(2)

Zemtsov, V.P. (Ed.). (2019). National report "High-tech business in regions of Russia," 2. Moscow: RANKhiGS. AIRP. 


\section{ENTREPRENEURSHIP AND SUSTAINABILITY ISSUES}

ISSN 2345-0282 (online) http://jssidoi.org/jesi/ 2019 Volume 7 Number 1 (September) http://doi.org/10.9770/jesi.2019.7.1(38)

Vlasov, A.I., Grigoriev, P.V, Krivoshein, A.I., Shakhnov, V.A., Filin, S. \& Migalin, V.S. (2018). Smart management of technologies: Predictive maintenance of industrial equipment using wireless sensor networks. Entrepreneurship and Sustainability Issues, 6(2), 489-502. https://doi.org/10.9770/jesi.2018.6.2(2)

WEF. (2018). Digital Transformation Initiative. Unlocking \$100 trillion for business and society from digital transformation. Executive summary, 12. Retrieved from http://reports.weforum.org/digital-transformation/wpcontent/blogs.dir/94/mp/files/pages/files/dti-executivesummary-20180510.

Veronika Yu. CHERNOVA, Associate Professor, Cand. Sci. (Economic), People's Friendships University of Russia, Department of Marketing; Institute of Marketing, State University of Management. Professional interests: world economy, marketing of transnational companies, importsubstitution, product personalization, one-to-one marketing, interactive marketing communications. Recent articles are published in a cooperation with research colleaques in a field of retailer's communication strategies; product personalization, managing data-driven advertising campaigns.

ORCID ID: orcid.org/0000-0001-5951-9091

Vasily S. STAROSTIN, Associate Professor, Cand. Sci. (Economic), Head of Advertising and PR Department, Institute of Marketing, State University of Management. Professional interests: product personalization, one-to-one marketing, interactive marketing communications. Recent articles are published in a cooperation with research colleaques in a field of retailer's communication strategies; product personalization, managing data-driven advertising campaigns.

ORCID ID: orcid.org/0000-0003-2243-7345

Ekaterina A. Degtereva, Associate Professor, Cand. Sci. (Economic), People's Friendships University of Russia, Department of Marketing. Professional interests: world economy, marketing of transnational companies, importsubstitution, product personalization, oneto-one marketing, interactive marketing communications. Recent articles are published in a cooperation with research colleaques in a field of retailer's communication strategies; product personalization, managing data-driven advertising campaigns.

ORCID ID: orcid.org/0000-0002-8752-5840

Inna V. ANDRONOVA, Professor, Dr. Sci. (Economic), Department of international economic relations, Peoples' Friendship University of Russia. Professional interests: world economy, import substitution, balance of exports and imports, economic security, interactive marketing communications, multinational corporations, marketing of transnational companies, balance of resources, food security risks, monetary policy.

ORCID ID: orcid.org/0000-0003-1940-6978

Register for an ORCID ID:

https://orcid.org/register

Copyright (C) 2019 by author(s) and VsI Entrepreneurship and Sustainability Center

This work is licensed under the Creative Commons Attribution International License (CC BY).

http://creativecommons.org/licenses/by/4.0/

(c) (i) Open Access 